\title{
Productivity and Quality Dynamics of Parching Sorghum Genotypes as Influenced by Nitrogen Management through Vermicompost during Rabi Season
}

\author{
Nilima Darekar*, Anita Chorey, W. V. More, A. N. Paslawar, \\ N. D. Parlawar and S. M. Sawadhkar \\ Department of Agronomy, Dr. Panjabrao Deshmukh Krishi Vidyapeeth, \\ Akola, 444 104(M.S.), India \\ *Corresponding author
}

\begin{tabular}{|l|}
\hline K e y w or d s \\
Parching sorghum, \\
Genotypes, \\
Nitrogen, \\
Management
\end{tabular}

\section{A B S T R A C T}

An experiment was conducted on "Productivity and quality dynamics of parching sorghum genotypes as influenced by nitrogen management through vermicompost during rabi season" of 2018-19. The results revealed that among the parching sorghum genotypes, Gulbhendi Local-1 showed significantly higher growth attributes viz., plant height, dry matter plant $^{-1}$ and stem diameter as compared to genotype Phule madhur at harvest. However, the parching sorghum genotype Phule madhur showed significantly more number of leaves, leaf area plant ${ }^{-1}$ and leaf : stem ratio over genotype Gulbhendi Local-1. With reputes to yield attributes, the parching sorghum genotype Phule madhur recorded higher green hurda yield over the genotype Gulbhendi Local-1 and found significantly superior of the parching sorghum genotype Gulbhendi Local-1. However, the genotype Gulbhendi Local-1 recorded maximum green fodder yield and found significantly superior over the genotype Phule Madhur. The highest benefit: cost ratio was observed in Phule Madhur as compared to Gulbhendi Local-1 genotype. With regards to nitrogen management at harvest, application of $125 \% \mathrm{RDN}^{-1}$ through vermicompost recorded superior growth as well as yield attributes along with optimum B:C ratio and was found significantly superior over 100 percent $\mathrm{RDN}^{-1}$ ha ${ }^{-1}$ through vermicompost, 50 per cent RDN $\mathrm{ha}^{-1}$ through vermicompost and control, respectively. The experimental consequences revealed that with reputes to quality analysis of grain the parching sorghum genotype Phule Madhur found superior over Gulbhendi Local-1. Similarly, the results revealed that in respect of proximate analysis, the fodder from Gulbhendi Local-1 found superior over Phule madhur with respect to crude protein, crude fibre, Ether Extract and total ash. However, the genotype Phule Madhur found better in producing Nitrogen free extract. In respect of quality and proximate analysis, application of $125 \%$ RDN through vermicompost also proved significantly superior over other nitrogen management treatments. 


\section{Introduction}

Sorghum has good nutritional composition similar to rice and wheat in some aspects. The grains contain high fiber and non-starchy polysaccharides and starch with some unique characteristics. There is a considerable variation in sorghum for levels of proteins, lysine, lipids, carbohydrates, fiber, calcium, phosphorus, iron, thiamine and niacin (Shobha et al., 2008; Chavan et al., 2009). Protein quality and essential amino acid profile of sorghum is better than many of the cereals and millets. Sorghum in general is rich source of fiber and B-complex vitamins (Gopalan et al., 2000 and Patil et al., 2010).

Sorghum is rich in fiber and minerals, apart from having a sufficient quantity of carbohydrates $(72 \%)$, proteins $(11.6 \%)$ and fat $(1.9 \%)$. Starch is the major constituent of the grain. The protein in sorghum contains albumin globulin (15\%), prolamin (26\%) and glutelin (44\%). Sorghum does not contain gluten, hence the dough does not have stickiness, to roll with the chapatti roller. The flour from sorghum is gluten free and is a safe energy source for people allergic to gluten. The minimal amounts of flavanols and phytic acid are present in white sorghum (Chavan and Patil, 2010).

The tender jowar grains in Marathi is called as "hurda" and in Gujarati it is called as 'Ponk". Basically, hurda is roasted food product prepared from sweet sorghum on coal in mud pits which gives it an earthy taste. This freshly roasted hurda is then eaten with an accompaniment of various types of chutneys made up of sesame, groundnut, dry coconut, garlic and red chillies. Additives like jaggery, revdi, lime and miri shev make the taste more pleasant. According to a recent Guardian article American chefs say that sweet sorghum is the next 'wonder grain'. They extoll its health benefits, its versatility in cooking (among other things, it pops like corn) and its ecofriendliness due to being exceptionally drought-tolerant. (ICRISAT, 2013).

Hurda is referred to tender jowar available during late winter it is the main staple grain of rural Maharashtra. The period in early January when jowar grain is juicy and very tender which is roasted over cakes of dried cow dung then roasted hurda hold in bare palms, vigorous rubbing to separate roasted hurda from the chaff. Hurda could be another reason to do a winter trip to Maharashtra and head out into its fields where enterprising farmers now advertise hurda or ponk parties. Far from America's food trends, this is where sweet sorghum has always been celebrated at its seasonal best. The consumption of hurda has more importance and popular in India since ancient times because of its unique sweet taste. It is generally prepared by roasting over cakes of dried cow dung. Besides, sweet taste hurda has some nutritional properties, like good source of dietary fibers, proteins, minerals and carbohydrates. This can be a gluten free diet option for celiac patients. It helps in not only weight loss but also acts as a coolant for the body. Hurda is commonly eaten with the hull, which retains the majority of the nutrients and very high in fiber and iron, with a fairly high protein level and also a good source of phosphorus and thiamine. Hurda is rich in antioxidants and all sorghum varieties are gluten-free, an attractive alternative for wheat allergy sufferers.

The tender sweet sorghum (hurda) is known for its delicious taste. There is a need to popularize sorghum food as hurda with its high minerals and fiber content and with slow starch digestibility makes an ideal food for diabetic and obese population in the urban as well as rural society. Increasing urban population demand the hurda has increased 
many folds. This would be opportunity for farmers to fulfil the demand for supplying hurda and improve their farm earning. It was therefore felt to develop and identify the genotype for tender sweet sorghum (hurda) purpose which will give benefit to the farmers and consumers too. Now a day's agro-tourism business is increasing in the rural areas and in the contest of supplying sorghum hurda as a niche product get the more profit to the farmers and producers (Taylor et al., 2006).

\section{Methodology}

Field study investigation entitled, "Productivity and quality dynamics of parching sorghum genotypes as influenced by nitrogen management through vermicompost during rabi season" was conducted at Department of Agronomy, Dr. Panjabrao Deshmukh Krishi Vidyapeeth, Akola during rabi season of 2018-19. The soil of the experiment plot was clay loam in texture with $\mathrm{pH} \quad 8.3$ indicating alkaline reaction. The experiment was laid out in factorial randomized block design and three replications. The treatments comprises of two parching sorghum genotypes viz., $\mathrm{G}_{1}$-Phule Madhur, $\mathrm{G}_{2}$-Gulbhendi Local-1 and four nitrogen management treatments viz., $125 \%$ RDN ha ${ }^{-1}$ through vermicompost $(100 \mathrm{~kg} \mathrm{~N}$ $\mathrm{ha}^{-1}$ ), $100 \% \mathrm{RDN} \mathrm{ha}^{-1}$ through vermicompost $\left(80 \mathrm{~kg} \mathrm{~N} \mathrm{ha}^{-1}\right), 50 \% \mathrm{RDN}^{-1}$ vermicompost $\left(40 \mathrm{~kg} \mathrm{~N} \mathrm{ha}^{-1}\right)$ and control. The climate of the area is semi-arid characterized. Maximum temperature varies from 26.5 to $35.3{ }^{\circ} \mathrm{C}$ and minimum temperature from 9.4 to $19.3{ }^{\circ} \mathrm{C}$ during the growing period. Average relative humidity in the rabi season was ranged from 49 to $83 \%$ in morning hours and from 20 to $36 \%$ in evening hours. Rate of evaporation was higher during $2^{\text {nd }}$ to $7^{\text {th }} \mathrm{MW}$ than normal. It was lower during $49^{\text {th }}$ and $1^{\text {st }} \mathrm{MW}$ than normal. Whereas, the rainfall has received $47^{\text {th }}$ meteorological weeks. The soil was clay loam in texture, moderate in organic carbon, available nitrogen, and available phosphorus and fairly rich in available potash. The nitrogen management was carried out through vermicompost and applied to soil before sowing as per treatments. The quantity of vermicompost 1335, 2670 and $3337 \mathrm{~kg} \mathrm{ha}^{-1}$ was used to supply 50\%, $100 \%$ and $125 \%$ RDN, respectively. The control treatment comprised of no nutrient management.

\section{Results and Discussion}

The results obtained from the present investigation as well as relevant discussion have been summarized under following heads:

\section{Production traits}

The data pertaining to production traits as influenced by different treatments are in Table 1.

\section{Effect of genotypes}

The data pertaining to growth traits in Table 1 revealed that, the parching sorghum genotype Gulbhendi Local-1 showed significantly higher growth attributes such as plant height, dry matter plant ${ }^{-1}$ and stem diameter and was found significantly superior over genotype Phule Madhur at harvest. However, the parching sorghum genotype Phule Madhur recorded significantly higher growth attributes such as number of leaves plant $^{-1}$, leaf area plant $^{-1}$ and leaf:stem ratio plant $^{-1}$ found superior as compared to genotype Gulbhendi Local-1. This might be due to the vigorous growth habitats and adaptability of genotypes where it grown. Significantly higher green hurda yield $\left(\mathrm{kgha}^{-1}\right)$ of parching sorghum recorded by the genotype Phule Madhur and found significantly superior over the as compared to genotype Gulbhendi Local-1. The green fodder yield $\left(\mathrm{qha}^{-1}\right)$ of parching sorghum recorded maximum in the 
genotype Gulbhendi Local-1 and found significantly superior over the Phule Madhur genotype. This might be due to the growth habitats and adaptability of genotypes where it grown. The results are in conformity with Shinde et al., (2016). The benefit: cost ratio was highest in the Phule Madhur genotype (3.91:1) over the genotype Gulbhendi Local1. The higher partitioning of dry matter towards grain yield in genotype Phule Madhur. The genotype Phule Madhur was good in threshability which results into maximum hurda yield.

\section{Effect of Nitrogen management}

The data pertaining to growth traits in Table 1 revealed that, application of $125 \% \mathrm{RDN}^{-1}$ through vermicompost recorded sophisticated plant height, number of leaves plant ${ }^{-1}$, leaf area plant ${ }^{-1}$, leaf:stem ratio plant ${ }^{-1}$, dry matter plant $^{-1}$ and stem diameter plant ${ }^{-1}$ found significantly superior over control and comparable with $100 \% \mathrm{RDN}^{-1}$ through vermicompost, $50 \% \mathrm{RDN} \mathrm{ha}^{-1}$ through vermicompost at harvest, respectively.

The results conformity with Ahmad et al., (2007), Arbad et al., (2008), Satpal et al., (2015), Singh et al., (2016), Meena et al., (2017). The data pertaining to yield traits in Table 1 revealed that the treatment of nitrogen management with application of $125 \%$ RDN $\mathrm{ha}^{-1}$ though vermicompost recorded sophisticated green hurda yield $\left(\mathrm{kg} \mathrm{ha}^{-1}\right)$ was found significantly superior over other treatments i.e. application of $100 \% \mathrm{RDN} \mathrm{ha}^{-1}$ through vermicompost, $50 \%$ RDN ha $^{-1}$ through vermicompost and control at harvest, respectively. As, the treatment of nitrogen management with application of $125 \%$ RDN $\mathrm{ha}^{-1}$ though vermicompost recorded sophisticated green fodder yield $\left(\mathrm{q} \mathrm{ha}{ }^{-1}\right)$ was found significantly superior over control and comparable with $100 \%$ RDN ha ${ }^{-1}$ through vermicompost, $50 \%$ RDN ha ${ }^{-1}$ through vermicompost at harvest, respectively. The results are in conformity with Patidar (2004). With regards to the Benefit : Cost ratio was found more in control treatments over other nitrogen management treatments with application of $100 \%$ RDN $\mathrm{ha}^{-1}$ through vermicompost, $50 \%$ RDN ha ${ }^{-1}$ through vermicompost and control, respectively. As the Benefit: Cost ratio was found significantly more in control treatments due to there was no expence regarding to vermicompost but quality was imperior.

\section{Organoleptic parameters}

The data pertaining to organoleptic parameters viz., aroma, taste and threshability as influenced by different treatments are calculated by the rating scale given below and are presented in Table 2 .

\section{Rating Scale}

\begin{tabular}{|l|c|l|c|l|c|l|}
\hline Aroma & $\mathbf{1}$ & Good & $\mathbf{2}$ & Fair & $\mathbf{3}$ & No aroma \\
\hline Taste & 1 & Very sweet & 2 & Medium sweet & 3 & Slightly sweet \\
\hline Threshability & 1 & Free & 1.5 & Medium & 2 & Hard \\
\hline
\end{tabular}

\section{Effect of genotype}

Both the genotypes Phule Madhur and Gulbhendi Local-1 was found good in aroma along with very sweet taste. However, with reputes to threshability, genotype Phule Madhur found free than the genotype Gulbhendi Local-1. The results are in conformity with Shide et al., (2016) and Darekar et al., (2019). 
Table.1 Mean Production traits as affected by nitrogen management in parching sorghum

\begin{tabular}{|c|c|c|c|c|c|c|c|c|c|c|}
\hline Treatments & $\begin{array}{l}\text { Height } \\
\text { (cm) }\end{array}$ & $\begin{array}{c}\text { Number } \\
\text { of } \\
\text { leaves } \\
\text { plant }^{-1}\end{array}$ & $\begin{array}{c}\text { Leaf } \\
\text { area } \\
\text { plant }^{-1} \\
\left(\mathbf{d m}^{2}\right)\end{array}$ & $\begin{array}{l}\text { Leaf : } \\
\text { stem } \\
\text { ratio }\end{array}$ & $\begin{array}{c}\text { Dry } \\
\text { matter } \\
\text { accumulation }_{\left(\text {g plant }^{-1}\right)}\end{array}$ & $\begin{array}{c}\text { Stem } \\
\text { Girth } \\
\text { (cm) }\end{array}$ & $\begin{array}{l}\text { Days to } \\
\text { soft } \\
\text { dough } \\
\text { stage }\end{array}$ & $\begin{array}{l}\text { Green } \\
\text { Hurda } \\
\text { Yield } \\
\text { (kg/ha) }\end{array}$ & $\begin{array}{c}\text { Fodder } \\
\text { Yield } \\
\text { (t/ha) }\end{array}$ & $\begin{array}{l}\mathrm{B}: \mathrm{C} \\
\text { ratio }\end{array}$ \\
\hline \multicolumn{11}{|c|}{ Factor A-Genotypes } \\
\hline $\mathbf{G}_{1}$-Phule Madhur & 181.5 & 10.58 & 36.766 & 2.46 & 147 & 1.6167 & 97 & 3978 & 41.14 & 3.91 \\
\hline $\mathbf{G}_{2}$-Gulbhendi Local- & 224.3 & 9.367 & 35.999 & 2.23 & 158 & 1.815 & 96.3 & 3107 & 58.55 & 3.74 \\
\hline $\mathbf{S E}(\mathbf{m}) \pm$ & 1.257 & 0.096 & 0.078 & 0.08 & 0.26 & 0.0199 & 0.19 & 64.8 & 0.84 & - \\
\hline CD at $5 \%$ & 3.813 & 0.29 & 0.2367 & 0.23 & 0.8 & 0.0603 & 0.56 & 197 & 2.549 & - \\
\hline \multicolumn{11}{|c|}{ Factor B- Nitrogen management } \\
\hline $\begin{array}{c}\mathrm{N}_{1}-125 \% \mathrm{RDN} \mathrm{ha}^{-1} \text { as } \\
\text { Vermicompost }\end{array}$ & 215 & 10.27 & 37.235 & 2.7 & 157 & 1.8533 & 98.3 & 4601 & 52.54 & 3.39 \\
\hline $\begin{array}{l}\mathrm{N}_{2}-100 \% \mathrm{RDN} \mathrm{ha}^{-1} \text { as } \\
\text { Vermicompost }\end{array}$ & 207 & 10.18 & 37.033 & 2.45 & 154 & 1.74 & 97 & 3843 & 51.1 & 3.25 \\
\hline $\begin{array}{l}\mathrm{N}_{3}-50 \% \mathrm{RDN} \mathrm{ha}^{-1} \text { as } \\
\text { Vermicompost }\end{array}$ & 199 & 10.05 & 35.888 & 2.18 & 152 & 1.6833 & 96.2 & 3092 & 49.09 & 3.73 \\
\hline $\mathbf{N}_{4}$-Control & 190.4 & 9.4 & 35.373 & 2.05 & 149 & 1.5867 & 95.2 & 2634 & 46.64 & 4.92 \\
\hline $\mathrm{SE}(\mathrm{m}) \pm$ & 1.778 & 0.135 & 0.1104 & 0.11 & 0.37 & 0.0281 & 0.26 & 91.6 & 1.188 & - \\
\hline CD at $5 \%$ & 5.393 & 0.41 & 0.3348 & 0.33 & 1.13 & 0.0853 & 0.79 & 278 & 3.604 & - \\
\hline
\end{tabular}


Table. 2 Organoleptic parameter regarding parching sorghum as influenced by various treatments

\begin{tabular}{|c|c|c|c|}
\hline Treatment & Aroma & Taste & Threshability \\
\hline $\mathbf{G}_{\mathbf{1}} \mathbf{N}_{\mathbf{1}}$ & 1 & 1 & 1 \\
\hline $\mathbf{G}_{\mathbf{1}} \mathbf{N}_{\mathbf{2}}$ & 1 & 1 & 1 \\
\hline $\mathbf{G}_{\mathbf{1}} \mathbf{N}_{\mathbf{3}}$ & 1 & 1 & 1 \\
\hline $\mathbf{G}_{\mathbf{1}} \mathbf{N}_{\mathbf{4}}$ & 1 & 1 & 1 \\
\hline $\mathbf{G}_{\mathbf{2}} \mathbf{N}_{\mathbf{1}}$ & 1 & 1 & 1.5 \\
\hline $\mathbf{G}_{\mathbf{2}} \mathbf{N}_{\mathbf{2}}$ & 1 & 1 & 1.5 \\
\hline $\mathbf{G}_{\mathbf{2}} \mathbf{N}_{\mathbf{3}}$ & 1 & 1 & 1.5 \\
\hline $\mathbf{G}_{\mathbf{2}} \mathbf{N}_{\mathbf{4}}$ & 1 & 1 & 1.5 \\
\hline
\end{tabular}

\section{Effect of nitrogen management}

Aroma and taste were not influenced by the different nitrogen management treatment. Threshability was not influenced by the different nitrogen management treatment. The results are in conformity with Darekar et al., (2019).

\section{Quality and proximate analysis}

The data pertaining to Quality and Proximate analysis as influenced by different treatments are are presented in Table 3 .

\section{Effect of genotypes}

The data pertaining to quality analysis( in hurda grain) in Table 3 revealed that, the parching sorghum genotype Phule Madhur showed significantly higher quality attributes such as reducing sugar (\%), non-reducing sugar(\%), total sugar $(\%)$ along with protein content $(\%)$ and was found significantly superior over genotype Gulbhendi Local-1. However, with repute towards the proximate analysis (in green fodder) revealed that, the parching sorghum genotype Gulbhendi Local-1 recorded more value of crude protein $\%$, crude fibre $\%$, ether extract $\%$ as well as total ash $\%$ and found significantly superior over the parching sorghum genotype Phule Madhur. The results are with conformity of Darekar et al., (2019).

\section{Effect of nitrogen management}

The data pertaining to quality analysis ( in hurda grain) in Table 3 revealed that, the treatment with application of $125 \% \mathrm{RDN} \mathrm{ha}^{-1}$ through vermicompost significantly higher quality attributes such as reducing sugar (\%), non-reducing sugar(\%), total sugar (\%) along with protein content $(\%)$ and was found significantly superior over other treatments of nitrogen management viz. with application of $100 \% \mathrm{RDN} \mathrm{ha}^{-1}$ through vermicompost, 50\% RDN ha ${ }^{-1}$ as vermicompost and control, respectively.

However, with repute towards the proximate analysis (in green fodder) revealed that, significantly higher crude protein, ether extract, total ash and nitrogen free extract was observed with application of $125 \% \mathrm{RDN}^{\mathrm{a}} \mathrm{a}^{-1}$ through vermicompost as compared to application of $100 \%$ RDN ha ${ }^{-1}$ through vermicompost, $50 \%$ RDN $\mathrm{ha}^{-1}$ as vermicompost and control, respectively. 
Table.3 Mean quality (in green hurda) and proximate (in green fodder) analysis affected by nitrogen management in parching sorghum

\begin{tabular}{|c|c|c|c|c|c|c|c|c|c|}
\hline Treatments & $\begin{array}{l}\text { Reducing } \\
\text { sugar }(\%)\end{array}$ & $\begin{array}{l}\text { Non-reducing } \\
\text { sugar }(\%)\end{array}$ & $\begin{array}{c}\text { Total sugar } \\
(\%)\end{array}$ & $\begin{array}{c}\text { Protein } \\
(\%)\end{array}$ & $\begin{array}{c}\text { Crude } \\
\text { Protein \% }\end{array}$ & $\begin{array}{c}\text { Crude } \\
\text { Fibre \% }\end{array}$ & $\begin{array}{c}\text { Ether } \\
\text { Extract \% }\end{array}$ & $\begin{array}{c}\text { Total Ash } \\
\%\end{array}$ & NFE \% \\
\hline \multicolumn{10}{|c|}{ Factor A-Genotypes } \\
\hline$G_{1}$-Phule Madhur & 1.01 & 11.76 & 12.77 & 11.26 & 8.11 & 29.03 & 1.62 & 8.12 & 53.12 \\
\hline $\mathbf{G}_{2}$-Gulbhendi Local-1 & 0.8 & 8.11 & 8.19 & 10.34 & 8.29 & 29.14 & 1.71 & 8.21 & 52.70 \\
\hline $\mathrm{SE}(\mathbf{m}) \pm$ & 0.03 & 0.20 & 0.20 & 0.06 & 0.03 & 0.19 & 0.02 & 0.01 & 0.12 \\
\hline CD at $5 \%$ & 0.09 & 0.60 & 0.61 & 0.19 & 0.10 & 0.56 & 0.08 & 0.04 & 0.35 \\
\hline \multicolumn{10}{|c|}{ Factor B- Nitrogen management } \\
\hline $\begin{array}{c}\mathrm{N}_{1}-125 \% \mathrm{RDN} \mathrm{ha}^{-1} \text { as } \\
\text { Vermicompost }\end{array}$ & 1.31 & 11.12 & 12.44 & 11.75 & 8.33 & 28.16 & 1.71 & 8.21 & 53.60 \\
\hline $\begin{array}{c}\mathrm{N}_{2}-100 \% \mathrm{RDN} \mathrm{ha}^{-1} \text { as } \\
\text { Vermicompost }\end{array}$ & 1.00 & 9.30 & 10.31 & 10.84 & 8.24 & 28.51 & 1.68 & 8.17 & 53.50 \\
\hline $\begin{array}{c}\mathrm{N}_{3-50}-\mathbf{R D N} \text { ha }^{-1} \text { as } \\
\text { Vermicompost }\end{array}$ & 1.14 & 10.89 & 12.03 & 10.50 & 8.16 & 29.48 & 1.66 & 8.15 & 52.57 \\
\hline $\mathbf{N}_{4}$ - Control & 0.84 & 8.82 & 9.66 & 10.31 & 8.07 & 30.18 & 1.63 & 8.12 & 51.99 \\
\hline $\mathrm{SE}(\mathrm{m}) \pm$ & 0.04 & 0.28 & 0.29 & 0.09 & 0.05 & 0.26 & 0.04 & 0.02 & 0.16 \\
\hline CD at $5 \%$ & 0.12 & 0.85 & 0.87 & 0.27 & 0.14 & 0.80 & 0.11 & 0.05 & 0.50 \\
\hline
\end{tabular}


However, control treatment recorded significantly higher crude fibre over the other nitrogen management treatments. This might may be due to Increase in crude protein content of fodder sorghum may definitely, be due to the fact that nitrogen often plays a great role in the synthesis of protein. Increase in crude protein content (\%) of fodder sorghum with increase in nitrogen levels have been reported by Muhammad et. al. (2011), Dhar et al., (2003) and Bhilare et.al. (2002) which confirms the results obtained in present investigation.

The parching sorghum genotype Gulbhendi Local-1 was found superior in growth attributes, green fodder yield along with proximate analysis over the genotype Phule Madhur. The parching sorghum genotype Phule Madhur was found superior in yield attributes as well as quality and organoleptic parameter over the genotype Gulbhendi Local-1. The nitrogen management treatment with application of $125 \% \mathrm{RDN} \mathrm{ha}^{-1}$ through vermicompost found superior in all growth, yield and quality attributes.

\section{References}

Arbad, B. K.; Ismail, S.;Shinde, D. N. and Dhage, S. J. (2008). Impact of integrated nutrient management practices on yield,nutrient concentration and nutrient uptake in sweet sorghum [Sorghum biocolor (L.) Moench].Asian Journal of Soil Science.3 (2): 269-271.

Bhilare, R. L., V.S.Patil, and A. G. Hiray (2002). Effects of $\mathrm{N}$ levels and time of $\mathrm{N}$ application on forage yield of sorghum. Forage Research 28(1): 3234.

Chavan, U. D., Patil, J. V. and Shinde M. S. (2009). Nutritional and roti quality of sorghum genotypes. Indonesian Journal of Agriculture Science. 10: 80-87.

Chavan U. D. and Patil J. V. (2010). Grain
Sorghum Processing. IBDC Publishers, Lucknow, India. 67-72

Darekar NK, Chorey AB, Sawadhkar SM, Hiwale SD, Patil SC and Jane DG. (2019). Organoleptic and proximate characteristics of parching sorghum genotypes in response to management of nitrogen. IJCS 2019; 7(5): 3074-3077

Dhar S., S. D.Gupta, S. N. Tripathi and S. K. Rai. (2003). Response of fodder sorghum varieties to nitrogen and sowing time. Range Management and Agro forestry 24(2): 132-134.

Gopalan C., Sastry B. V. and Balsubramanyam S. C. (2000). Nutritive Value of Indian Foods. National Institute of Nutrition. I.C.M.R., Hyderabad. 23.

ICRISAT. (2013). Study of Farmers Preference for different Varieties, Production and Consumption trends and Export Competitiveness of Sorghum in SAT India. ICRISAT, Patancheru, India. 22.

Meena, Ravi Shanker, Singh, Devendra and Jat, Bhanwar Lal (2017). Response of single-cut fodder sorghum genotypes to fertility levels under rainfed conditions of Rajasthan. Internat. J. Agric. Engg., 10(2): $\quad 423-440, \quad$ DOI: 10.15740/HAS/IJAE/10.2/423-440.

Muhammad, A., Asif, I., Muhammad. S. Ibni. Z., Muhammad. M. and Muhammad. A. (2011). Effect of different nitrogen levels and seed rates on yield and quality of maize fodder, Crop and environment 2(2): 47-51.

Patidar, M.I. and Mali, A.L. (2004). Effect of farmyard manure, fertility levels and bio-fertilizers on growth, yield and quality of sorghum (Sorghum bicolor).Indian Journal of Agronomy.49 (2): 170-120.

Patil P. B., Sajjanar G. M., Biradar B. D., Patil H. B. and Devarnavadagi S. B. (2010). Technology of hurda production 
by microwave oven. Journal of Dairying, Foods and Home Sciences. 29: 232-236.

Satpal, Duhan BS, Joshi UN, Godara AS, Arya S and Neelam. (2015). Response of yield, quality and economics of single cut foragesorghum genotypes to different nitrogen and phosphorus levels.Forage Research 41 (3):170-175

Shinde M. S., Awari V. R., Patil V. R., Gadakh S. R., Dalvi U. S., Chavan U. D. and Nirmal S.V. (2016). Phule madhur (RSSGV-46): a sweet grain rabi sorghum variety for tender grain processing. International Journal of Science, Environment and Technology.
5(3): $1362-1369$.

Singh Kendra Pal, Chaplot P. C., Sumeriya H. K., and Gopal Lal Choudhary. (2016). Performance of single-cut forage sorghum genotypes to fertility levels. forage res., 42 (2) : pp. 140-142.

Shobha V., Kasturiba B., Naik R. K. and Yenagi N. (2008). Nutritive Value and Quality Characteristics of Sorghum Genotypes. Karnataka Journal of Agriculture Science. 20: 586-588.

Taylor J. R. N., Schober T. J. and Bean S. R. (2006). Novel food and non-food uses for sorghum and millets. Journal of Cereal Science. 44:252-271.

\section{How to cite this article:}

Nilima Darekar, Anita Chorey, W. V. More, A. N. Paslawar, N. D. Parlawar and Sawadhkar. S. M. 2020. Productivity and Quality Dynamics of Parching Sorghum Genotypes as Influenced by Nitrogen Management through Vermicompost during Rabi Season. Int.J.Curr.Microbiol.App.Sci. 9(02): 2956-2964. doi: https://doi.org/10.20546/ijcmas.2020.902.337 